\title{
BMJ Open Utilisation and outcomes of allogeneic hematopoietic cell transplantation in Ontario, Canada, and New York State, USA: a population-based retrospective cohort study
}

Samantha Aliza Hershenfeld (D) , John Matelski, ${ }^{2}$ Vicki Ling, ${ }^{3}$ Michael Paterson, ${ }^{3}$ Matthew Cheung, ${ }^{1,4}$ Peter Cram (i) ${ }^{1,2}$

To cite: Hershenfeld SA,

Matelski J, Ling V, et al. Utilisation and outcomes of allogeneic hematopoietic cell transplantation in Ontario, Canada, and New York State, USA: a populationbased retrospective cohort study. BMJ Open 2020;10:e039293. doi:10.1136/ bmjopen-2020-039293

- Prepublication history and additional material for this paper is available online. To view these files, please visit the journal online (http://dx.doi.org/10. 1136/bmjopen-2020-039293).

Received 14 April 2020 Revised 22 September 2020 Accepted 23 September 2020

Check for updates

(C) Author(s) (or their employer(s)) 2020. Re-use permitted under CC BY-NC. No commercial re-use. See rights and permissions. Published by BMJ.

For numbered affiliations see end of article.

Correspondence to

Dr Peter Cram;

peter.cram@uhn.ca

\section{ABSTRACT}

Objective Allogeneic haematopoietic cell transplantation (HCT) is a potentially curative treatment for haematologic and oncologic diseases. There is a perception that the United States of America (USA) offers greater access to expensive therapies such as HCT. Alternatively, Canada is thought to suffer from protracted wait times, but lower spending. Our objective was to compare HCT utilisation and short-term outcomes in Ontario (ON), Canada, and New York State (NY), USA.

Design, setting and participants We conducted a population-based cohort study using administrative health data to identify all residents of $\mathrm{ON}$ and NY who underwent allogeneic HCT between 2012 and 2015.

Primary and secondary outcome measures The primary outcome measures were age and sex standardised HCT utilisation rates, in-hospital mortality, hospital length of stay (LOS) and readmission rates in ON and NY. Secondary outcomes included comparing ON and NY HCT recipients with respect to demographic characteristics and patient wealth (using neighbourhood income quintile).

Results We identified 547 HCT procedures in ON and $1361 \mathrm{HCT}$ procedures performed in NY. HCT recipients in ON were younger than NY (mean age 49.0 vs 51.6 years; $\mathrm{p}<0.001$ ) and a lower percentage of ON recipients resided in affluent neighbourhoods compared with NY (47.2\% vs $52.6 \% ; p=0.026)$. Utilisation of HCT was 14.4 per 1 million population per year in $\mathrm{ON}$ and 26.7 per 1 million per year in NY $(p<0.001)$. The magnitude of the $0 N-N Y$ difference in utilisation was larger for older patients. In-hospital mortality, LOS and readmission rates were lower in ON than NY in both unadjusted and adjusted analyses. Conclusions We found significantly lower utilisation of HCT in ON compared with NY, particularly among older patients. Higher in-hospital mortality in NY relative to ON requires further study. These differences are thought provoking for patients, healthcare providers and policymakers in both jurisdictions.

\section{INTRODUCTION}

Allogeneic haematopoietic cell transplantation (HCT) is a potentially curative
Strengths and limitations of this study

- Population-based evaluation of all allogeneic haematopoietic cell transplantations (HCTs) performed on all adult residents of each jurisdiction using large well-studied administrative databases.

- Precise estimates of utilisation rates for HCT by age, sex and neighbourhood income level in two countries with differing healthcare systems.

- In-hospital outcomes including mortality, length of stay and readmissions.

- Lack of clinical detail regarding patient comorbidities and clinical indications for HCT.

Lack of data on post discharge outcomes.

treatment for multiple haematological and oncologic diseases including acute leukaemias, lymphomas, myelodysplastic syndromes (MDS) and other less common conditions. ${ }^{12}$ Clinical practice guidelines for HCT in Canada and the USA are quite similar and there is no obvious biological reason to suspect markedly different underlying differences in rates of haematologic conditions necessitating HCT.

Investigators in both countries commonly participate in large clinical trials and regularly update guidelines to reflect new evidence. ${ }^{1-5}$

The number of HCTs being performed globally has been increasing for the past decade as a consequence of a growing and ageing population, expansion of HCT to include older patients and new indications for HCT to include certain non-malignant conditions such as haemoglobinopathies. ${ }^{16-9}$ Increasing demand for HCT is challenging for payers because of the estimated costs of US\$80000-US\$200000 for the initial transplant and short-term (90 days) follow-up. ${ }^{10-12}$ 
Despite general agreement on the indications for HCT and relatively similar cancer incidence rates across countries, ${ }^{13-15}$ there are very few empirical studies comparing utilisation of HCT in different countries. ${ }^{16-18}$ Many of these studies are older and few include data from either Canada or the USA.

We sought to compare utilisation and short-term outcomes for HCT in Ontario (ON), Canada, and New York State (NY), USA. We were motivated by several factors, including widespread public concerns that erupted in ON in 2015 that HCT capacity was insufficient and that patients were suffering harm, ${ }^{19}{ }^{20}$ but limited data characterising a shortfall in capacity. ${ }^{182} 22$ Moreover, Canada-USA comparison not only affords the opportunity to compare HCT in two countries with many similarities (a common border, close geopolitical relationships, racially diverse populations), but also striking differences in terms of culture, financing and delivery of healthcare services. ${ }^{23}$

Our a priori hypothesis was that ON would have lower per capita utilisation of HCT than NY and that HCT utilisation would be higher in both jurisdictions among residents from wealthier neighbourhoods. As prior Canada-USA comparison studies have demonstrated longer hospital length of stay (LOS) but lower readmission rates in Canada as compared with the USA, ${ }^{24}{ }^{25}$ we also hypothesised in the present study that patients receiving HCT in ON would have a longer LOS, but lower readmission rates and similar short-term mortality.

\section{METHODS \\ Data}

We used population level administrative health data from $\mathrm{ON}$ and NY to identify all adults (age $\geq 18$ years) who underwent inpatient allogeneic HCT between 2012 and 2015. Our primary data source for ON was the 2012-2015 Canadian Institute for Health Information Discharge Abstract Database (DAD), which has been extensively used for similar research studies. These administrative records provide information on all hospitalisations paid for by the Ontario Health Insurance Plan (OHIP); OHIP provides health insurance to all legal residents of $\mathrm{ON}$ ( $\sim 99 \%$ of the population), which covers virtually $100 \%$ of inpatient hospitalisations. ${ }^{26}{ }^{27}$ Though there have been some limited case series reporting outpatient HCT, these have generally described single-centre experiences, and the vast majority of HCT in both countries are performed in the inpatient setting. ${ }^{28-30}$ ON's DAD provides information regarding patient demographics (age, sex), primary and secondary diagnoses coded using International Classification of Diseases Version 10 (ICD-10) diagnosis codes, procedures captured using Canadian Classification of Health Interventions (CCI) codes, discharge disposition (eg, died in hospital, home, transfer to another acute care hospital), a unique patient identifier (used to track patients over time) and unique hospital identifiers. Comorbid conditions present during the index hospitalisation were identified using the Quan ICD-10 adaptation of the Elixhauser comorbidity coding scheme, which maps ICD-10 coded comorbidities to ICD-9. ${ }^{31}$

Our primary data source for NY was the 2012-2015 State Inpatient Database (SID), which has been used extensively in prior research. ${ }^{24}{ }^{32}$ The SID contains administrative data for all patients admitted to acute care hospitals, with the exception of a small number of military veterans hospitals and psychiatric hospitals none of which perform HCT $^{33}$ Data elements for each admission include patient demographics, primary and secondary diagnosis and procedures (coded using International Classification of Diseases, Ninth Revision, Clinical Modification (ICD-9-CM codes)), discharge disposition, patient identifier and hospital identifier. Comorbid conditions present at the time of the index hospital stay were captured using algorithms developed by Elixhauser et $a l^{34}$ which has been used extensively in prior research studies. ${ }^{35}$

Estimates of the NY population were obtained from the US Census Data; estimates of the ON population were obtained from the analogous Canadian Census Data. We linked the NY data to the American Hospital Association annual survey to ascertain information regarding hospital teaching status and bed size. We linked the ON DAD to the OHIP Registered Persons Database for mortality information, and to information from the Ontario Ministry of Health and Long-Term Care for hospital characteristics. Multiple ON datasets were linked using unique encoded identifiers and analysed at ICES.

\section{Cohort generation}

We identified adults aged $\geq 18$ years who underwent allogeneic HCT between 1 January 2012 and 30 September 2015 using CCI codes in ON and ICD-9-CM codes for NY that have been used in prior HCT research (online supplemental table 1). ${ }^{6}{ }^{36-38}$ We excluded patients with missing age or sex, age $\geq 105$ years at the time of their HCT, patients who underwent their HCT in 2011 but were subsequently discharged in 2012 and patients whose index hospital stay was implausibly short ( $\leq 1$ day) because this would be incompatible with receiving an HCT. We excluded patients who died on the day of index procedure or prior to the index procedure. We excluded patients who had received HCT in the 2 years prior to study initiation (1 January 2010 to 31 December 2011) because the index procedure in such patients could represent a complication of an earlier HCT. We also limited our cohort to patients for whom HCT was listed in the primary procedure field in NY (or first procedure field in $\mathrm{ON}$ ) to avoid counting readmissions or patients with a prior HCT as de novo procedures. We excluded patients who underwent a second hospitalisation for HCT within $<180$ days of the first HCT, as the second hospitalisation could represent a complication of the earlier procedure.

\section{Statistical analyses}

First, we compared demographics, comorbidities and the percentage of patients who resided in higher and lower 
income neighbourhoods among patients in $\mathrm{ON}$ and $\mathrm{NY}$ using simple bivariate measures. In each jurisdiction, we used each patient's zip code or postal code of residence to link them to their corresponding neighbourhood-level census data. Patients were then stratified into income quintiles (quintile $1=$ lowest income, quintile $5=$ highest income) and subsequently grouped into low (quintiles 1-2), intermediate (quintile 3) and high (quintile 4-5) groups. We compared the percentage of HCT recipients residing in low, intermediate and high income neighbourhoods in ON and NY. We performed an exploratory analysis assessing for common HCT indications using ICD-10 and ICD-9 for ON and NY based on coding schemes used in prior studies ${ }^{10-49}$ (see online supplemental table 1). As each patient record contains fields for multiple diagnoses, we selected the first relevant indication code that appeared, allowing for only a single indication for each patient.

Second, we compared the percentage of all acute care hospitals in ON and NY that performed HCT and mean/ median annual hospital HCT volumes. We also compared ON and NY hospitals with respect to bed size and teaching status (teaching vs not).

Third we compared per capita utilisation of HCT (procedures per 1000000 population per year) for adults in ON and NY. The numerator for these calculations was the total number of allo-HCTs performed in each jurisdiction while the denominator was the number of adults age $\geq 18$ years in each jurisdiction derived from census data. We calculated age and sex standardised utilisation rates using a direct standardisation approach. ${ }^{45}$

Fourth, we compared unadjusted outcomes in $\mathrm{ON}$ and NY including hospital LOS, in-hospital mortality and hospital readmission within 30 and 180 days of discharge among those who survived to discharge. We conducted stratified analyses comparing demographics and in-hospital mortality among HCT recipients in ON and NY who were older and younger than 60 years of age. Finally, we used generalised estimating equations to compare riskstandardised outcomes in $\mathrm{ON}$ and NY using two sequential models: Model 1 adjusted for only patient age and sex; Model 2 for Model 1 factors plus hospital HCT volume and LOS.

Our study protocol and analyses were prespecified (online supplemental appendix 1) and registered with Open Science prior to the initiation of any statistical analysis (https://osf.io/m8jqf/). All analyses were performed using either SAS (Version 9.4, Cary, North Carolina) or R statistical software packages.

\section{Patient and public involvement}

It was not appropriate or possible to involve patients or the public in the design, or conduct, or reporting, or dissemination plans of our research. However, our study was motivated by both public and government concerns about whether $\mathrm{ON}$ was providing adequate numbers of HCT. ${ }^{19-22}$ Our results will be disseminated to the ON government and the public in accordance with the ICES policies.

\section{RESULTS}

Our cohort consisted of 547 HCT procedures in ON performed on 545 individual patients and 1361 procedures performed on 1333 individual patients in NY between 2012 and 2015 (online supplemental figure1 $\mathrm{A}, \mathrm{B})$. The mean age of patients who received HCT in ON was significantly younger than NY (49.0 vs 51.6; $p<0.001)$ while the percentage of HCT recipients who were women was similar between jurisdictions (table 1). There were significant differences between jurisdictions in the indication for HCT (table 1). For example, acute myeloid leukaemia (AML) was listed as the primary diagnosis in ON and NY for $41.8 \%$ and $22.2 \%$ of HCTs, respectively, $(\mathrm{p}<0.001)$, while MDS was the primary diagnosis for $9.9 \%$ in $\mathrm{ON}$ and $11.8 \%$ in $\mathrm{NY}(\mathrm{p}=0.28)$ (table 1). A higher percentage of HCT recipients in NY resided in affluent neighbourhoods (quintiles 4 or 5) compared with $\mathrm{ON}$ (52.6\% in NY vs $47.2 \%$ in ON; $\mathrm{p}=0.04$ ) (table 1 ). A smaller percentage of ON patients underwent 2 or more HCTs relative to $\mathrm{NY}(\mathrm{p}=0.02)$.

In ON, 2.4\% of acute hospitals performed HCT as compared with $5.4 \%$ in $\mathrm{NY}(\mathrm{p}=0.16)$, which represents 3.7 and 7.8 hospitals performing HCT per 10 million population, respectively. Mean annual hospital HCT volumes were similar in $\mathrm{ON}$ and $\mathrm{NY}$ (38.8 vs 32.4; $\mathrm{p}=0.10$ ) (table 2).

The overall utilisation of HCT was significantly lower in ON than NY (14.4 vs 26.7 HCTs per million adult population per year $[\mathrm{p}<0.001]$ ) (table 3 ). The $\mathrm{ON}-\mathrm{NY}$ difference in utilisation was relatively small among younger adults (eg, 4.9 fewer HCTs per million in ON as compared with NY among adults age $<50$ years), but increased progressively with increasing age (figure 1 and table 3 ).

Unadjusted LOS was shorter in ON than NY (33.6 vs 36.3 days; $\mathrm{p}=0.01$ ) and in-hospital mortality was lower in ON compared with NY (3.7\% vs $6.4 \%$; $\mathrm{p}=0.02)$ (table 4$)$. When stratified by age, younger HCT recipients (age <60) had similar in-hospital mortality in ON and NY $(4.6 \%$ vs $6.7 \% ; \mathrm{p}=0.17$ ), whereas older recipients (age $\geq 60$ ) had lower in-hospital mortality in ON compared with $\mathrm{NY}$ $(1.3 \%$ vs $5.9 \%$; $p=0.02)$. The significantly lower in-hospital mortality in ON compared with NY persisted in analyses adjusting for age, sex, LOS and hospital volume (online supplemental table 2).

Unadjusted rates of hospital readmission within 30 and 180 days of hospital discharge were both significantly lower in ON compared with NY (table 4). In adjusted analyses, compared with patients in NY, patients in ON had significantly lower LOS and lower 30-day readmission rates (online supplemental table 2).

A secondary analysis compared demographics between HCT recipients stratified by age $(<60$ compared with $\geq 60$ years) (online supplemental table 3 ). The differences in comorbidities between $\mathrm{ON}$ and $\mathrm{NY}$ were similar to the non-stratified analysis, with most comorbidities, such as, 
Table 1 Characteristics of patients who underwent allogeneic haematopoietic cell transplantation in Ontario and New York in 2012-2015

\begin{tabular}{|c|c|c|c|}
\hline & $\begin{array}{l}\text { Ontario } \\
(\mathrm{N}=545)\end{array}$ & $\begin{array}{l}\text { New York } \\
(\mathrm{N}=1333)\end{array}$ & $P$ value \\
\hline Age, mean(SD) & $49.0(13.7)$ & $51.6(14.1)$ & $<0.001$ \\
\hline Age, $<50$, number (\%) & $241(44.2)$ & $489(36.7)$ & 0.002 \\
\hline Age, 50-59, number (\%) & $159(29.2)$ & $376(28.2)$ & 0.67 \\
\hline Age, 60-69, number (\%) & $136(25.0)$ & $400(30.0)$ & 0.03 \\
\hline Age, $\geq 70$, number (\%) & $9(1.7)$ & $68(5.10)$ & 0.001 \\
\hline Female, N (\%) & $239(43.9)$ & $581(43.6)$ & 0.92 \\
\hline \multicolumn{4}{|l|}{ Comorbid conditions } \\
\hline $\begin{array}{l}\text { Congestive heart } \\
\text { failure }\end{array}$ & $11(2.0)$ & $91(6.8)$ & $<0.001$ \\
\hline Depression & $33(6.1)$ & $185(13.9)$ & $<0.001$ \\
\hline $\begin{array}{l}\text { Hypertension with } \\
\text { complications }\end{array}$ & $0(0.0)$ & $445(33.4)$ & $<0.001$ \\
\hline $\begin{array}{l}\text { Diabetes without } \\
\text { complications }\end{array}$ & $56(10.3)$ & $110(8.3)$ & 0.16 \\
\hline $\begin{array}{l}\text { Chronic obstructive } \\
\text { pulmonary disease }\end{array}$ & $19(3.5)$ & $108(8.1)$ & $<0.001$ \\
\hline Renal failure & $11(2.0)$ & $47(3.5)$ & 0.09 \\
\hline \multicolumn{4}{|l|}{ Indications } \\
\hline AML & $228(41.8)$ & $296(22.2)$ & $<0.001$ \\
\hline MDS & $54(9.9)$ & $157(11.8)$ & 0.28 \\
\hline ALL & $59(10.8)$ & $113(8.5)$ & 0.11 \\
\hline CML & $29(5.3)$ & $51(3.8)$ & 0.15 \\
\hline CLL & $24(4.4)$ & $34(2.6)$ & 0.04 \\
\hline $\begin{array}{l}\text { Non-Hodgkin's } \\
\text { lymphoma }\end{array}$ & $9(1.7)$ & $87(6.5)$ & $<0.001$ \\
\hline Multiple myeloma & $10(1.8)$ & $34(2.6)$ & 0.35 \\
\hline Unspecified/other & $132(24.3)$ & $718(53.9)$ & $<0.001$ \\
\hline \multicolumn{4}{|l|}{ Neighbourhood income* } \\
\hline Income quintiles 1-2 & $184(33.8)$ & $421(31.7)$ & 0.36 \\
\hline Income quintile 3 & $104(19.1)$ & $209(15.7)$ & 0.07 \\
\hline Income quintile 4-5 & $257(47.2)$ & $699(52.6)$ & 0.04 \\
\hline
\end{tabular}

*Quintile 1=lowest income neighborhood; Quintile 5=highest income neighborhood.

ALL, acute lymphocytic leukaemia; AML, acute myeloid leukaemia; CLL, chroniclymphocytic leukaemia; CML, chronic myeloid leukaemia; MDS, myelodysplastic syndrome.

congestive heart failure and hypertension present less often in ON than in NY. Differences between indications were also similar, with AML being a more common indication in ON compared with NY, and unspecified indication more common in NY in both age groups. A higher percentage of the age $\geq 60$ years HCT recipients in NY resided in the highest income quintiles compared with $\mathrm{ON}$, whereas there was no significant differences between $\mathrm{ON}$ and NY with respect to HCT recipient income quintile in the age $<60$ years group.
Table 2 Characteristics of hospitals that performed HCT in Ontario and New York

\begin{tabular}{|c|c|c|c|}
\hline & $\begin{array}{l}\text { Ontario } \\
\text { (N=165) }\end{array}$ & $\begin{array}{l}\text { New York } \\
(\mathrm{N}=224)\end{array}$ & $P$ value \\
\hline $\begin{array}{l}\text { Hospitals performing } \\
\text { procedure, number (\%) }\end{array}$ & $4(2.4)$ & $12(5.4)$ & 0.16 \\
\hline $\begin{array}{l}\text { Annual procedural } \\
\text { volume, mean (SD) }\end{array}$ & $38.8(41.1)$ & $32.4(32.9)$ & 0.10 \\
\hline $\begin{array}{l}\text { Annual procedural } \\
\text { volume, median (IQR) }\end{array}$ & $27(15-63)$ & $22.9(8.9-49.6)$ & $\mathrm{N} / \mathrm{A}$ \\
\hline Bed number, mean (SD) & $600(240)$ & $1244.8(759.1)$ & $<0.001$ \\
\hline $\begin{array}{l}\text { Major teaching, number } \\
(\%)\end{array}$ & $4(100)$ & $8(100)$ & 1 \\
\hline
\end{tabular}

\section{DISCUSSION}

In an analysis of administrative data from ON, Canada, and NY, USA, we found significant differences in utilisation and outcomes of HCT. While overall per capita utilisation of HCT was approximately $60 \%$ higher in NY than in ON, utilisation was $200 \%$ higher in NY among adults age $\geq 60$ years of age. Unexpectedly, we observed significantly lower in-hospital mortality in $\mathrm{ON}$ that persisted even after adjustment for differences in age. In aggregate, our study provides compelling evidence of the importance of cross-border comparative studies and provides important lessons for healthcare providers and policymakers in both jurisdictions.

Several of our findings warrant elaboration. First, our finding of significantly lower utilisation of HCT in ON compared with NY adds important data to the contentious debate over access to HCT in ON. ${ }^{19-22}$ In 2015, there was widespread media coverage in ON suggesting that HCT capacity was insufficient after several tragic deaths of Canadian patients with haematologic conditions. In response, the $\mathrm{ON}$ government made substantial investment to expand capacity, including funding a new HCT centre ${ }^{621}{ }^{22}$ We found virtually no existing empirical data describing HCT utilisation in ON or how utilisation rates in $\mathrm{ON}$ compare with other countries. Without such information, policy-makers in ON (or any other jurisdiction) lack empirical data to guide crucial decisions about whether access to HCT is adequate.

In understanding our study, it is important to review the existing research on HCT utilisation. Gratwohl et al used 2006 data from centres participating in the Worldwide Network for Bone Marrow Transplant to study utilisation of both autologous and allogeneic HCT across 71 countries. $^{18}$ They found a lower utilisation rate in Canada (reported as between 5 and 30 HCTs per million population per year) compared with the USA ( $>30$ per million per year) but their study lacked the granularity of our analysis, and included both allogeneic and autologous HCT. Our study adds significantly to the existing literature on HCT utilisation differences ${ }^{18}{ }^{46-48}$ by fully capturing all allogeneic HCTs performed on adult residents of each jurisdiction over our study period, thus providing accurate measures of the true number of HCTs 
Table 3 Per capita Haematopoietic cell transplantation counts and utilisation in Ontario and New York (procedures per 1000 000 adult population per year)

\begin{tabular}{|c|c|c|c|c|c|c|c|}
\hline & \multicolumn{2}{|l|}{ Ontario } & \multicolumn{2}{|l|}{ New York } & \multicolumn{2}{|c|}{ Utilisation* } & \multirow[t]{2}{*}{$P$ value } \\
\hline & Procedures & Population & Procedures & Population & Ontario & New York & \\
\hline Total & 547 & 10859071 & 1361 & 15053173 & 14.4 & 26.7 & $<0.001$ \\
\hline$<50$ years & 242 & 5998021 & 500 & 8711634 & 11.5 & 16.4 & $<0.001$ \\
\hline $50-59$ years & 159 & 2010129 & 385 & 2657336 & 22.6 & 41.5 & $<0.001$ \\
\hline$\geq 70$ years & 9 & 1403334 & 69 & 1844732 & 1.8 & 11.1 & $<0.001$ \\
\hline
\end{tabular}

*Utilisation for New York directly standardised to match the age and sex of the Ontario population.

performed. Our study provides convincing evidence that HCT utilisation is lower in ON than in NY. While it might be tempting to jump to the conclusion that our study provides evidence that HCT utilisation is too high in $\mathrm{NY}$ or too low in $\mathrm{ON}$, we would argue against hasty assumptions. In particular, we lack detailed clinical data that would allow us to ascertain the 'appropriateness' of HCT at the individual patient level.

Second, our study should be considered in the context of the economic implications of expanding HCT utilisation in ON or reducing utilisation in NY, recognising that we lack the nuanced data to determine precisely what the ideal utilisation rate might be. It should be noted that healthcare spending is far lower in Canada than in the USA $(11.5 \%$ vs $17.6 \%$ of gross domestic product in 2015). ${ }^{49} 50$ The cost of HCT has been estimated at US\$80 000-US\$200000 during the 90 days post transplant period. ${ }^{10} 11$ If $\mathrm{ON}$ were to increase HCT utilisation to the NY rate (eg, from 14 per million to 26 per million), this would translate into an additional 105 HCTs annually at a cost of approximately US\$10500000. Alternatively, if NY were to reduce the yearly HCT rate by $25 \%$ from 26 per million to 20 per million per year, this would translate into 90 fewer HCTs per year in NY and a US\$13500 000 reduction in spending. Again, it is important to stress that we lack clear data on what the correct utilisation rate might be, but considering the cost implications is instructive.

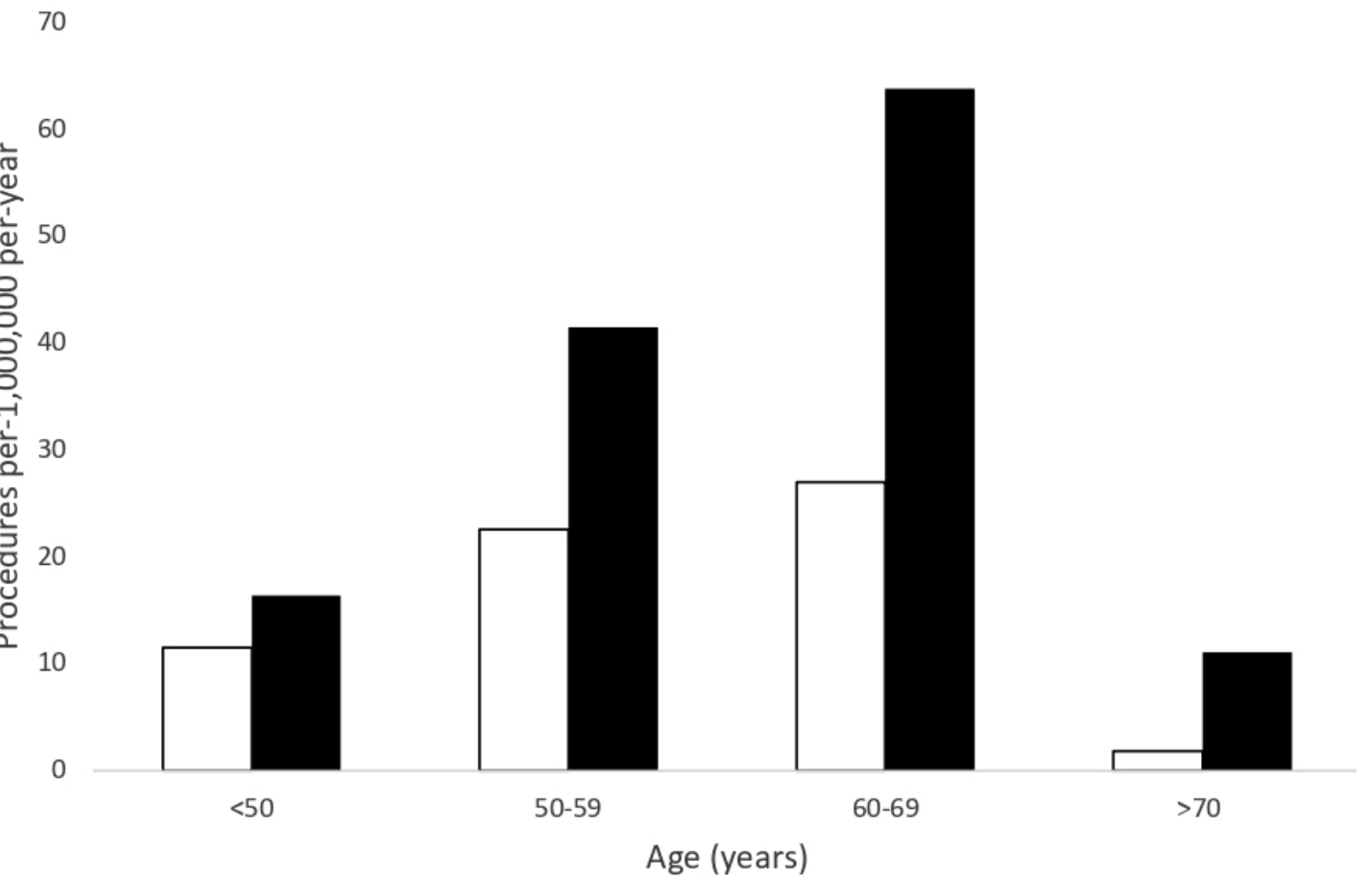

口Ontario

New York

Figure 1 Haematopoietic cell transplantation (HCT) utilisation in Ontario and New York. Utilisation rates in Ontario and New York reported as procedures per 1000000 adult population per year, stratified by HCT recipient age. Utilisation for New York directly standardised to match the age and sex of the Ontario population. 
Table 4 Unadjusted outcomes for recipients of Haematopoietic cell transplantation in Ontario and New York

\begin{tabular}{lccc}
\hline & $\begin{array}{l}\text { Ontario } \\
\text { (N=547) }\end{array}$ & $\begin{array}{l}\text { New York } \\
\text { (N=1361) }\end{array}$ & P value \\
\hline $\begin{array}{l}\text { Length of stay, mean (SD) } \\
\text { Discharge disposition }\end{array}$ & $32.6(17.9)$ & $36.3(23.4)$ & $<0.001$ \\
\hline $\begin{array}{l}\text { Died in-hospital, number } \\
\text { (\%) }\end{array}$ & $17(3.1)$ & $87(6.4)$ & 0.01 \\
\hline $\begin{array}{l}\text { Home, number (\%) } \\
\text { Transfer to another }\end{array}$ & $386(88.8)$ & $1231(90.4)^{\star}$ & 0.29 \\
$\begin{array}{l}\text { acute care hospital, } \\
\text { number (\%) }\end{array}$ & $2(0.1)$ & $<0.001$ \\
\hline $\begin{array}{l}\text { Post acute care, (\%) } \\
\text { Readmission }\end{array}$ & $11(2.0)$ & $40(2.9)$ & 0.26 \\
\hline $\begin{array}{l}\text { 30-day hospital } \\
\text { readmission, number } \\
\text { (\%) }\end{array}$ & $140(26.4)$ & $393(30.8)$ & 0.06 \\
\hline $\begin{array}{l}\text { 180-day hospital } \\
\text { readmission, number } \\
\text { (\%) }\end{array}$ & $303(57.2)$ & $784(61.5)$ & 0.08 \\
\hline $\begin{array}{l}\text { Number of readmissions } \\
\text { per patient at 180 days, } \\
\text { mean (SD) }\end{array}$ & $1.8(1.2)$ & $1.4(1.7)$ & $<0.001$ \\
\hline
\end{tabular}

*1 patient in New York was discharged to 'other' location.

Third, our finding that the higher HCT utilisation in $\mathrm{NY}$ relative to $\mathrm{ON}$ was relatively modest in younger adults (eg, 20\% higher at age <50), but increased progressively with advancing age $(100 \%$ higher at age $50-59,650 \%$ higher at age $>70$ ) is noteworthy. The American Society for Blood and Marrow Transplantation 2015 HCT guidelines specifically say that 'age by itself should not be a contraindication to transplantation in patients who may benefit from this procedure'. ${ }^{1}$ Other agencies such as Cancer Care Ontario (CCO) and the European Society for Bone Marrow Transplantation are also non-specific, pointing out that global health and frailty are more important considerations than chronologic age. ${ }^{251}$

Our finding of significantly higher in-hospital mortality in NY compared with ON, largely driven by significantly higher mortality for patients of age $\geq 60$ years in NY relative to ON warrants careful thought. The higher mortality observed in NY persisted in analyses that adjusted for age, sex and hospital volume adding robustness to our analyses. Given the implausibly large differences in comorbidity between our $\mathrm{ON}$ and NY HCT recipients and our lack of detailed clinical information required to calculate the Haematopoietic Cell Transplant-specific Comorbidity Index, we are unable to adjust for comorbid illness. ${ }^{52}$ Nevertheless, the higher shortterm mortality we observed in NY clearly warrants further study and verification.

A number of other findings warrant brief mention. We observed differences in the primary indication identified for HCT with ON having a higher proportion of patients with AML, and NY a higher proportion of patients with unspecified indications. There are small but significant differences in HCT guidelines, with The American Society of Bone and Marrow Transplantation listing HCT as standard of care for haemoglobinopathies, myeloproliferative neoplasms, and immunodeficiency syndromes while CCO remarks that due to limited evidence, they are unable to provide guidance for these conditions. ${ }^{12}$ However, we would urge readers to interpret the incidence of indications for HCT in our study with caution, serving more as an exploratory analysis requiring further study. The administrative databases used lacked granular detail regarding indications for HCT; and furthermore, the reliability of ICD codes for some commonly transplanted conditions have not been thoroughly studied in the literature.

Our finding that a similar percentage of hospitals in ON and NY offered HCT with similar mean volumes was unexpected as we hypothesised a smaller percentage of ON hospitals would perform HCT but with higher volumes. However, the lower median volume in NY does suggest a larger proportion of low-volume HCT centres in NY. The number of HCTs we identified in $\mathrm{ON}$ correlate well with numbers reported by $\mathrm{CCO}$, while the numbers from $\mathrm{NY}$ correlate reasonably well with numbers reported by the Center for International Blood and Marrow Transplant Research, adding rigour to our findings. 653

Our study has several limitations. Our analysis is limited to administrative data from one Canadian province and one US state, which may impact generalisability of our results to the national level. Second, we lacked detailed clinical data with respect to patient comorbidities and indications for HCT and were limited to the detail included in our administrative data. The prevalence of common comorbidities such as hypertension in ON appears to be quite low relative to NY, which is almost certainly an artefact of differences coding practices rather than a true reflection of the burden of comorbidities in the population. This precludes us from comparing ON and NY HCT recipients with respect to comorbidities, which would be important in interpreting the differences in outcomes we observed. Indications for HCT were inferred based on ICD codes in administrative databases. However this analysis should be considered exploratory and interpreted with caution; $24.3 \%$ of $\mathrm{ON}$ patients and $53.9 \%$ of $\mathrm{NY}$ patients did not have any common indication coded for HCT, which makes it difficult to draw conclusions around whether differences in indications impact HCT practice in the two jurisdictions. Future studies comparing indications for HCT between the two regions are warranted. Third, though our study demonstrates a significant difference in HCT utilisation between $\mathrm{ON}$ and $\mathrm{NY}$, we are unable to definitively comment on overuse and/or underuse in each jurisdiction. Fourth, while our study provides important data on utilisation in ON and NY both overall and stratified by age, we did not examine whether access to HCT is distributed equitably across other important variables such as socioeconomic status, race/ ethnicity, or geography (rural/urban); it would be interesting to know whether Canada's universal health insurance coverage might mitigate some of the socioeconomic differences recently reported by Paulson et al. ${ }^{54}$ Fourth, While HCT in both jurisdictions is virtually exclusively performed in the inpatient setting, it is possible that some components of the 
HCT could be performed in the outpatient setting. Our reliance on inpatient data prevents us from exploring this issue. Lastly, with the administrative databases used in this study, we are limited to in-hospital mortality as an outcome and are unable to comment on deaths that occurred after discharge or longer term outcomes. Similarly, we were unable to accurately assess cause of death using the data we had available. Further studies comparing longer-term survival post HCT and cause of death in $\mathrm{ON}$ and $\mathrm{NY}$ are needed.

In conclusion, we found that $\mathrm{ON}$ has significantly lower utilisation of HCT compared with NY, particularly at older age. We also observed significantly higher mortality in NY that did not appear to be explained by differences in age. Overall our results provide much needed information on HCT utilisation and outcomes that should be considered by healthcare providers and policy-makers in both jurisdictions.

\section{Author affiliations}

${ }^{1}$ Faculty of Medicine, University of Toronto, Toronto, Ontario, Canada

${ }^{2}$ Division of General Internal Medicine and Geriatrics, Sinai Health System and University Health Network, Toronto, Ontario, Canada

${ }^{3}$ Institute for Clinical Evaluative Sciences (ICES), Toronto, Ontario, Canada ${ }^{4}$ Odette Cancer Centre, Sunnybrook Health Sciences Centre, Toronto, Ontario, Canada

Acknowledgements This study was supported by Institute for Clinical Evaluative Science (ICES). Parts of this material are based on data and information compiled and provided by the Canadian Institute for Health Information (CIHI). The opinions, results and conclusions reported in this paper are those of the authors and are independent from the data providers and funding sources. No endorsement by $\mathrm{ClHI}$, ICES or the Ontario Ministry of Health is intended or should be inferred.

Contributors SAH, MC and PC designed the research. SAH, JM and VL performed research. JM, VL, SAH and PC analysed data. MP, PC, MC and SAH wrote the paper.

Funding University of Toronto, Faculty of Medicine and US National Institute of Aging (grant number: R01AG058878)

Competing interests None declared.

Patient consent for publication Not required.

Ethics approval This analysis was approved by the Research Ethics Board at University Health Network, Toronto.

Provenance and peer review Not commissioned; externally peer reviewed.

Data availability statement $\mathrm{ON}$, Canada data are not available for sharing due to Ontario governmental privacy restrictions. NY SID data are publicly available for purchase through the AHRQ central distributor. Statistical code may be available from the authors.

Supplemental material This content has been supplied by the author(s). It has not been vetted by BMJ Publishing Group Limited (BMJ) and may not have been peer-reviewed. Any opinions or recommendations discussed are solely those of the author(s) and are not endorsed by BMJ. BMJ disclaims all liability and responsibility arising from any reliance placed on the content. Where the content includes any translated material, BMJ does not warrant the accuracy and reliability of the translations (including but not limited to local regulations, clinical guidelines, terminology, drug names and drug dosages), and is not responsible for any error and/or omissions arising from translation and adaptation or otherwise.

Open access This is an open access article distributed in accordance with the Creative Commons Attribution Non Commercial (CC BY-NC 4.0) license, which permits others to distribute, remix, adapt, build upon this work non-commercially, and license their derivative works on different terms, provided the original work is properly cited, appropriate credit is given, any changes made indicated, and the use is non-commercial. See: http://creativecommons.org/licenses/by-nc/4.0/.

\section{ORCID IDs}

Samantha Aliza Hershenfeld http://orcid.org/0000-0002-6978-1816

Peter Cram http://orcid.org/0000-0002-1910-346X
REFERENCES

1 Majhail NS, Farnia SH, Carpenter PA, et al. Indications for Autologous and Allogeneic Hematopoietic Cell Transplantation: Guidelines from the American Society for Blood and Marrow Transplantation. Biol Blood Marrow Transplant 2015;21:1863-9.

2 Imrie K, Rumble RB, Crump M. The Advisory Panel on Bone Marrow and Stem Cell Transplantation; Hematology Disease Site Group of Cancer Care Ontario's Program in Evidence-based Care. Stem Cell Transplantation in Adults. Toronto (ON: Cancer Care Ontario. Program in Evidence-based Care Recommendation Report, 2009.

3 Oliansky DM, Antin JH, Bennett JM, et al. The role of cytotoxic therapy with hematopoietic stem cell transplantation in the therapy of myelodysplastic syndromes: an evidence-based review. Biol Blood Marrow Transplant 2009;15:137-72.

4 Oliansky DM, Appelbaum F, Cassileth PA, et al. The role of cytotoxic therapy with hematopoietic stem cell transplantation in the therapy of acute myelogenous leukemia in adults: an evidence-based review. Biol Blood Marrow Transplant 2008;14:137-80.

5 Koreth J, Schlenk R, Kopecky KJ, et al. Allogeneic stem cell transplantation for acute myeloid leukemia in first complete remission: systematic review and meta-analysis of prospective clinical trials. JAMA 2009;301:2349-61.

6 Cancer Care Ontario. Complex malignant hematology services in Ontario, 2017. Available: https://archive.cancercare.on.ca/common/ pages/UserFile.aspx?fileld=381199 [Accessed 1 May 2019].

7 Center for International Blood and Marrow Transplant Research. Current uses and outcomes of hematopoietic cell transplantation (HCT): CIBMTR summary slides, 2018. Available: https://www.cibmtr. org/ReferenceCenter/SlidesReports/SummarySlides/pages/index. aspx [Accessed 1 May 2019].

8 Passweg JR, Baldomero $\mathrm{H}$, Bader P, et al. Use of haploidentical stem cell transplantation continues to increase: the 2015 European Society for blood and marrow transplant activity survey report. Bone Marrow Transplant 2017;52:811-7.

9 Passweg JR, Baldomero H, Basak GW, et al. The EBMT activity survey report 2017: a focus on allogeneic HCT for nonmalignant indications and on the use of non-HCT cell therapies. Bone Marrow Transplant 2019;54:1575-85.

10 Majhail NS, Mau LW, Denzen EM, et al. Costs of autologous and allogeneic hematopoietic cell transplantation in the United States: a study using a large national private claims database. Bone Marrow Transplant 2013;48:294-300.

11 Khera N, Zeliadt SB, Lee SJ. Economics of hematopoietic cell transplantation. Blood 2012;120:1545-51.

12 Preussler JM, Denzen EM, Majhail NS. Costs and cost-effectiveness of hematopoietic cell transplantation. Biol Blood Marrow Transplant 2012;18:1620-8.

13 Shysh AC, Nguyen LT, Guo M, et al. The incidence of acute myeloid leukemia in Calgary, Alberta, Canada: a retrospective cohort study. BMC Public Health 2017;18:94.

14 Cancer Statistics Center, American Cancer Society. Leukemia at a glance. Available: https://cancerstatisticscenter.cancer.org/?_ga= 2.135542264.871561029.1564446226-1315160246.1564446226\#!/ cancer-site/Leukemia [Accessed 1 May 2019].

15 Canadian Cancer Society, Government of Canada. Canadian cancer statistics 2015; special topic: predictions of the future burden of cancer in Canada. Available: http://www.cancer.ca/ /media/ cancer.ca/CW/cancer\%20information/cancer\%20101/Canadian\% 20cancer\%20statistics/Canadian-Cancer-Statistics-2015-EN.pdf?la= en [Accessed 1 May 2019].

16 Gratwohl A, Passweg J, Baldomero H, et al. Economics, health care systems and utilization of haematopoietic stem cell transplants in Europe. Br J Haematol 2002;117:451-68.

17 Gratwohl A, Hermans J, Goldman JM, et al. Bone marrow transplantation in Europe: major geographical differences. The European Group for Bone Marrow Transplantation [EBMT]. J Intern Med 1993;233:333-41.

18 Gratwohl A, Baldomero H, Aljurf M, et al. Hematopoietic stem cell transplantation: a global perspective. JAMA 2010;303:1617-24.

19 Canadian Broadcasting Corporation website. Her dying wish.' Ontario parents want speedier stem cell transplants after daughter's death. Available: https://www.cbc.ca/radio/asithappens/as-ithappens-thursday-edition-1.3568451/her-dying-wish-ontarioparents-want-speedier-stem-cell-transplants-after-daughter-s-death1.3568464 [Accessed 20 Apr 2019].

20 The Star website. Ontario opens access to more stem-cell transplants. Available: https://www.thestar.com/news/canada/2016/ 05/01/ontario-opens-access-to-more-stem-cell-transplants.html [Accessed 20 Apr 2019].

21 Canadian Broadcasting Corporation website. Ontario spending millions sending cancer patients to U.S. for stem cell transplants, 
auditor finds. Available: https://www.cbc.ca/news/canada/toronto/ auditor-general-report-2017-healthcare-cancer-1.4435567 [Accessed 20 Apr 2019].

22 City News Toronto website. Leukemia patients wait up to three months for stem cell transplant. Available: https://toronto.citynews. $\mathrm{ca} / 2016 / 02 / 11 /$ leukemia-patients-wait-up-to-three-months-for-stemcell-transplant/ [Accessed 20 Apr 2019].

23 Ridic G, Gleason S, Ridic O. Comparisons of health care systems in the United States, Germany and Canada. Mater Sociomed 2012;24:112-20.

24 Cram P, Landon BE, Matelski J, et al. Hip and knee arthroplasty utilization and outcomes in the United States and Canada: an analysis of new York and Ontario administrative data. Arthritis Rheumatol 2018;70:547-54.

25 Cram P, Landon BE, Matelski J, et al. Utilization and outcomes for spine surgery in the United States and Canada. Spine 2019;44:1371-80.

26 Ravi B, Jenkinson R, Austin PC, et al. Relation between surgeon volume and risk of complications after total hip arthroplasty: propensity score matched cohort study. BMJ 2014;348:g3284.

27 Stukel TA, Fisher ES, Alter DA, et al. Association of hospital spending intensity with mortality and readmission rates in Ontario hospitals. JAMA 2012;307:1037-45.

28 Granot N, Storer BE, Cooper JP, et al. Allogeneic hematopoietic cell transplantation in the outpatient setting. Biol Blood Marrow Transplant 2019;25:2152-9.

29 Guru Murthy GS, Hari PN, Szabo A, et al. Outcomes of reducedintensity conditioning allogeneic hematopoietic cell transplantation performed in the inpatient versus outpatient setting. Biol Blood Marrow Transplant 2019;25:827-33.

30 McDiarmid S, Hutton B, Atkins $\mathrm{H}$, et al. Performing allogeneic and autologous hematopoietic SCT in the outpatient setting: effects on infectious complications and early transplant outcomes. Bone Marrow Transplant 2010;45:1220-6.

31 Quan $\mathrm{H}$, Sundararajan V, Halfon P, et al. Coding algorithms for defining comorbidities in ICD-9-CM and ICD-10 administrative data. Med Care 2005;43:1130-9.

32 White C. Cutting Medicare Hospital prices leads to a spillover reduction in hospital discharges for the nonelderly. Health Serv Res 2014:49:1578-95.

33 US Department of Veteran Affairs website. VA national transplant program. Available: https://www.va.gov/health/services/transplant/ [Accessed 1 May 2019].

34 Elixhauser A, Steiner C, Harris DR, et al. Comorbidity measures for use with administrative data. Med Care 1998;36:8-27.

35 Sharabiani MTA, Aylin P, Bottle A. Systematic review of comorbidity indices for administrative data. Med Care 2012;50:1109-18.

36 Maziarz RT, Guérin A, Gauthier G, et al. Five-Year direct costs of acute lymphoblastic leukemia pediatric patients undergoing allogeneic stem cell transplant. Int J Hematol Oncol 2016;5:63-75.

37 Kumar G, Ahmad S, Taneja A, et al. Severe sepsis in hematopoietic stem cell transplant recipients*. Crit Care Med 2015;43:411-21.

38 Canadian Institute for Health Information. Canadian classification of health interventions, 2012. Available: https://www.cihi.ca/en/cci volume_four_2012_en.pdf [Accessed 1 May 2019].

39 Bernstein CN, Nabalamba A. Hospitalization-based major comorbidity of inflammatory bowel disease in Canada. Can $\mathrm{J}$ Gastroenterol 2007;21:507-11.

40 Canadian Institute for Health Information. International statistical classification of diseases and related health problems tenth revision,
Canada. Available: https://www.cihi.ca/en/icd_volume_one_2015_en. pdf [Accessed 1 May 2019].

41 Baliunas D, Patra J, Rehm J, et al. Smoking-attributable morbidity: acute care hospital diagnoses and days of treatment in Canada, 2002. BMC Public Health 2007;7:247.

42 Mitchell JM, Conklin EA. Factors affecting receipt of expensive cancer treatments and mortality: evidence from stem cell transplantation for leukemia and lymphoma. Health Serv Res 2015;50:197-216.

43 Sanchez L, Sylvester M, Parrondo R, et al. In-Hospital mortality and post-transplantation complications in elderly multiple myeloma patients undergoing autologous hematopoietic stem cell transplantation: a population-based study. Biol Blood Marrow Transplant 2017;23:1203-7.

44 Reich C, Ryan PB, Stang PE, et al. Evaluation of alternative standardized terminologies for medical conditions within a network of observational healthcare databases. J Biomed Inform 2012;45:689-96.

45 Ko DT, Tu JV, Samadashvili Z, et al. Temporal trends in the use of percutaneous coronary intervention and coronary artery bypass surgery in New York state and Ontario. Circulation 2010;121:2635-44.

46 Niederwieser D, Baldomero H, Szer J, et al. Hematopoietic stem cell transplantation activity worldwide in 2012 and a SWOT analysis of the worldwide network for blood and marrow transplantation group including the global survey. Bone Marrow Transplant 2016;51:778-85.

47 Mohamed SYA, Fadhil I, Hamladji R-M, et al. Hematopoietic stem cell transplantation in the eastern Mediterranean region (EMRO) 2008-2009: report on behalf of the eastern Mediterranean bone marrow transplantation (EMBMT) group. Hematol Oncol Stem Cell Ther 2011;4:81-93.

48 Passweg JR, Baldomero H, Bader P, et al. Hematopoietic stem cell transplantation in Europe 2014: more than 40000 transplants annually. Bone Marrow Transplant 2016;51:786-92.

49 Centers for Medicare and Medicaid Services. National health expenditures by type of service and source of funds, cy 1960-2018, 2019. Available: https://www.cms.gov/Research-Statistics-Dataand-Systems/Statistics-Trends-and-Reports/NationalHealthEx pendData/NationalHealthAccountsHistorical [Accessed $25 \mathrm{Jul}$ 2020].

50 Canadian Institute for Health Information. National health expenditure trends 1975-2019. Ottawa, 2019. https://www.cihi.ca/en/nationalhealth-expenditure-trends-1975-to-2019

51 Carreras E, Dufour C, Mohty M, et al. The EBMT Handbook. 2019 ed. Switzerland: Springer Open, 2019. https://www.ebmt.org/sites/ default/files/2019-01/2019_Book_TheEBMTHandbook.pdf

52 Sorror ML. Comorbidities and hematopoietic cell transplantation outcomes. Hematology Am Soc Hematol Educ Program 2010;2010:237-47.

53 Health Reources \& Services Administration. Transplant activity report covering 2013-2017. Available: https://bloodstemcell.hrsa. gov/sites/default/files/bloodstemcell/data/transplant-activity/ transplants-year-cell-source-state-donor.pdf [Accessed 3 Mar 2020].

54 Paulson K, Brazauskas R, Khera N, et al. Inferior access to allogeneic transplant in disadvantaged populations: a center for international blood and marrow transplant research analysis. Biol Blood Marrow Transplant 2019;25:2086-90. 